\title{
Article
}

\section{Does Self-Myofascial Release Cause a Remote Hamstring Stretching Effect Based on Myofascial Chains? A Randomized Controlled Trial}

\author{
Paul Fauris ${ }^{1,2,+}+^{(D)}$, Carlos López-de-Celis ${ }^{1,2,3,+}$ (D) , Max Canet-Vintró ${ }^{1,2}$, Juan Carlos Martin ${ }^{1}$ (D), \\ Luis Llurda-Almuzara ${ }^{1,2} \mathbb{D}^{\mathbb{D}}$, Jacobo Rodríguez-Sanz ${ }^{1,2} \mathbb{D}$, Noé Labata-Lezaun ${ }^{1,2} \mathbb{D}$, Mathias Simon ${ }^{1,2}$ \\ and Albert Pérez-Bellmunt 1,2,*iD
}

check for updates

Citation: Fauris, P.; López-de-Celis, C.; Canet-Vintró, M.; Martin, J.C.; Llurda-Almuzara, L.; Rodríguez-Sanz, J.; Labata-Lezaun, N.; Simon, M.; Pérez-Bellmunt, A. Does Self-Myofascial Release Cause a Remote Hamstring Stretching Effect Based on Myofascial Chains? A Randomized Controlled Trial. Int. J. Environ. Res. Public Health 2021, 18 12356. https://doi.org/10.3390/ ijerph182312356

Academic Editor: Paul B. Tchounwou

Received: 4 October 2021

Accepted: 22 November 2021

Published: 24 November 2021

Publisher's Note: MDPI stays neutral with regard to jurisdictional claims in published maps and institutional affiliations.

Copyright: (c) 2021 by the authors. Licensee MDPI, Basel, Switzerland. This article is an open access article distributed under the terms and conditions of the Creative Commons Attribution (CC BY) license (https:// creativecommons.org/licenses/by/ $4.0 /)$.
1 Faculty of Medicine and Health Sciences, Universitat Internacional de Catalunya, 08017 Sant Cugat del Vallès, Spain; pfauris@uic.es (P.F.); carlesldc@uic.es (C.L.-d.-C.); maxcanet44@uic.es (M.C.-V.); jcmartin@uic.es (J.C.M.); lllurda@uic.es (L.L.-A.); jrodriguezs@uic.es (J.R.-S.); nlabata@uic.es (N.L.-L.); msimon@uic.es (M.S.)

2 ACTIUM Functional Anatomy Group, Universitat Internacional de Catalunya, 08195 Sant Cugat del Vallès, Spain

3 Institut Universitari per a la Recerca a I'Atenció Primària de Salut Jordi Gol i Gurina (IDIAPJGol), 08007 Barcelona, Spain

* Correspondence: aperez@uic.cat; Tel.: +34-93-5042000

+ Equal contribution.

Abstract: Background: The hamstring muscles are described as forming part of myofascial chains or meridians, and the superficial back line (SBL) is one such chain. Good hamstring flexibility is fundamental to sporting performance and is associated with prevention of injuries of these muscles. The aim of this study was to measure the effect of self-myofascial release (SMR) on hamstring flexibility and determine which segment of the SBL resulted in the greatest increase in flexibility. Methods: 94 volunteers were randomly assigned to a control group or to one of the five intervention groups. In the intervention groups, SMR was applied to one of the five segments of the SBL (plantar fascia, posterior part of the sural fascia, posterior part of the crural fascia, lumbar fascia or epicranial aponeurosis) for $10 \mathrm{~min}$. The analyzed variables were hamstring flexibility at $30 \mathrm{~s}, 2,5$, and $10 \mathrm{~min}$, and dorsiflexion range of motion before and after the intervention. Results: Hamstring flexibility and ankle dorsiflexion improved when SMR was performed on any of the SBL segments. The segments with the greatest effect were the posterior part of the sural fascia when the intervention was brief $(30 \mathrm{~s}$ to $2 \mathrm{~min}$ ) or the posterior part of the crural fascia when the intervention was longer ( 5 or $10 \mathrm{~min}$ ). In general, $50 \%$ of the flexibility gain was obtained during the first $2 \mathrm{~min}$ of SMR. Conclusions: The SBL may be considered a functional structure, and SMR to any of the segments can improve hamstring flexibility and ankle dorsiflexion.

Keywords: fascia; flexibility; hamstring muscles; self-myofascial release; meridians

\section{Introduction}

Classic anatomy textbooks describe the hamstring muscles from a traditional mechanistic view as being isolated from the adjacent structures [1-3] However, recent research has changed this perspective, proposing a connective tissue link between the active components of the movement system to form an extensive network of myofascial chains, or meridians [4]. Of these meridians, there is most anatomical evidence for the superficial back line (SBL) $[4,5]$. This myofascial chain, described by Myers, connects the hamstring muscles with the gastrocnemius muscles and the plantar fascia caudally, and with the thoracolumbar fasciae, the erector spinae muscle and the epicranial aponeurosis cranially [6]. Functionally, anatomical studies have demonstrated the role of these fascia in the trans- 
mission of biomechanical force between the different regions of the body connected by the chains [7-11].

The hamstring and gastrocnemius muscles have a fundamental role in sports performance; hamstring injuries are common and associated with a high rate of recurrence [12-14]. As a result, the etiology of a hamstring injury has been extensively researched, and several risk factors have been proposed. Some of these studies have reported that reduced hamstring flexibility is one of many factors that can predispose to hamstring muscle strains [14-19]. Previous investigations have pointed out that a lower range of motion (ROM) or flexibility $[20,21]$ and increased muscle stiffness [22,23] are risk factors for sports injuries [24]. Research has shown that increased muscle stiffness associated with antagonist muscle contractions can inhibit joint movement and result in higher energetic/metabolic costs [25]. Therefore, it could be essential to improve ROM and decrease muscle stiffness in sports and rehabilitation settings.

With the objectives to improve the ROM [26-28] and flexibility [29,30] and reduce the stiffness and pain [31] in the rehabilitation and sport field appear the self-myofascial release (SMR). Self-myofascial release (SMR) uses a foam roller involves the pressure of a person's own body weight to release tension in muscles, tendons, fascia, and/or soft tissues.

Although there is anatomical and functional evidence of some of these chains, to our knowledge no study has demonstrated a remote effect on hamstring or gastrocnemius flexibility from the use of a foam roller at distinct segments of the superficial back line (SBL). The present study aimed to address this research deficit, by measuring hamstring and gastrocnemius flexibility improvement when self-myofascial release was applied to the various segments of the SBL and determining - if such a remote effect were presentthe segment and duration of treatment that resulted in the greatest increase in flexibility. If this functional unit exists, this study could make it possible to propose new remote therapeutic strategies.

\section{Materials and Methods}

\subsection{Participants}

The participants recruited for the present study were healthy subjects. Of the 105 volunteers who were initially screened, 94 were enrolled. All details of the enrolment process appear in Figure 1.

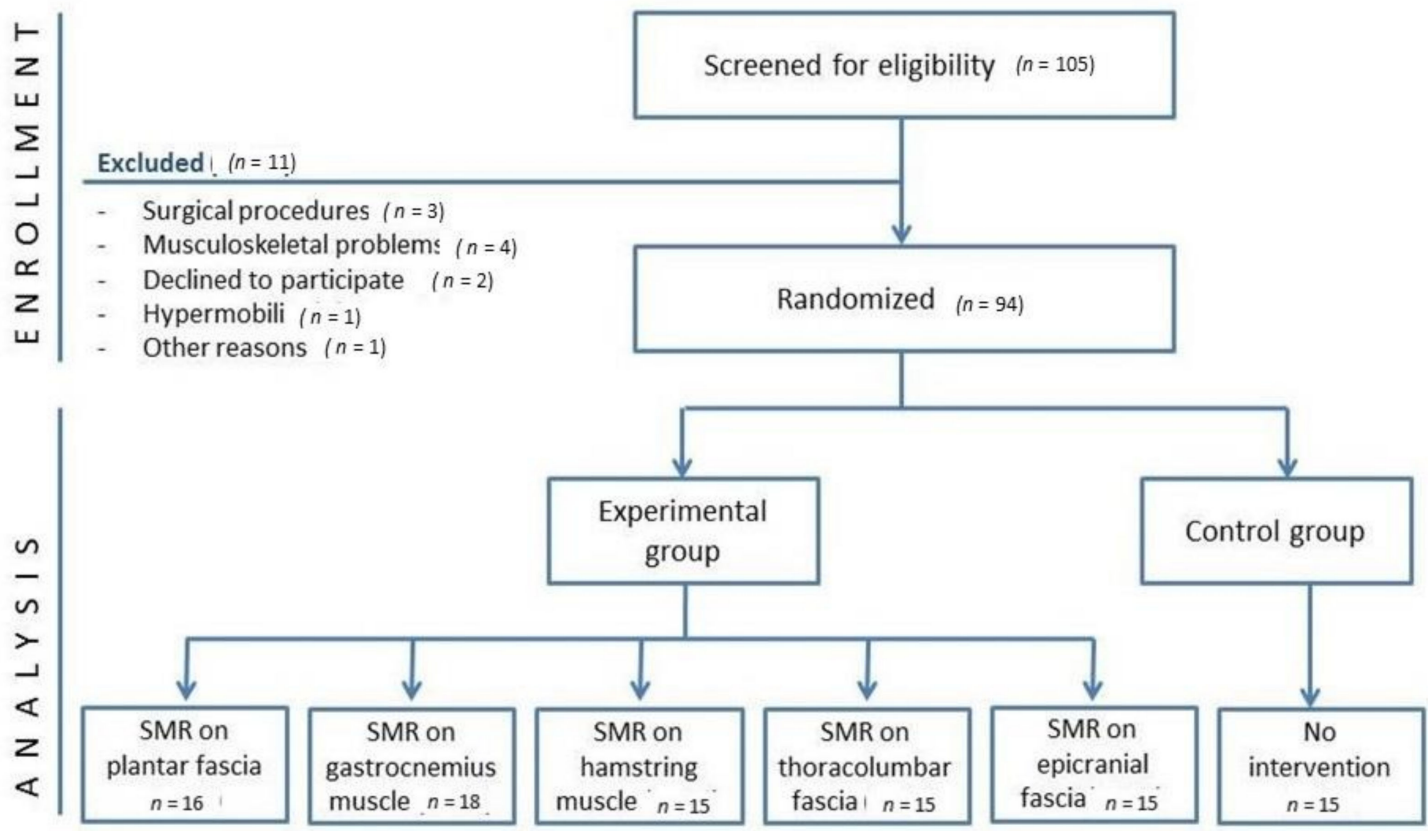

Figure 1. Flow chart of the trial. 
Approval was obtained from the local ethics committee (CBAS1805, 1 April 2018). and the study was conducted in accordance with the declaration of Helsinki. The trial was registered at clinicaltrials.gov. All participants gave written informed consent prior to testing.

Volunteers were asked to abstain from alcohol for $24 \mathrm{~h}$ priors to participation. Exclusion criteria were age below 18 years, surgical procedures in the previous 6 months, overweight or obese, previous hamstring injury or musculoskeletal problems in the previous 12 months, hypermobility, severe neurological or cardiovascular disease, pregnancy, and existing muscle soreness.

\subsection{Study Design}

The study was a single-blind randomized control trial (clinicaltrials.gov, accessed on 11 May 2018, NCT03521544). Interventions and measurements were carried out by the same 2 blindedtherapists, one controlling the intervention and the other taking measurements and recording data. To minimize bias, participants could not see and were not informed of any result obtained during measurement. A local committee approved this study (CBAS1805).

\subsection{Variables and Measurements}

Hamstring muscle flexibility was evaluated with a modified sit-and-reach test (MSR) before, during (at $30 \mathrm{~s}, 2$ and $5 \mathrm{~min}$ ) and at the end of the intervention (at $10 \mathrm{~min}$ ).

This test was selected based on its wide use by clinicians to evaluate hamstring flexibility and its convenient correlation coefficient [32-34]. It was carried out following the recommendations in previous published research [33,35]. The participants sat on the floor with the lower limbs stretched out and together, the back and hips supported against the wall $\left(90^{\circ}\right.$ hip flexion), and the soles of the feet placed against the edge of the box. Participants then extended their arms forward with the same hand on top of the other facing down, keeping their back against the wall. They then reached forward, sliding their hands along the measuring scale as far as possible without bending the knees [36].

Dorsiflexion range of motion of the ankle was analyzed with the dorsiflexion lunge test (DF-lunge), out before and after the intervention following the recommendations of previous investigations $[29,37]$. The test is performed by placing the foot perpendicular to a wall and lunging the knee towards the wall. The foot is sequentially moved farther away from the wall until the maximum range of dorsiflexion is achieved. As the heel should not lift off the floor, a band was placed under the heel and tension applied by the therapist, so that if the heel raised off the floor the band would snap loose. The distance from the tiptoe to the wall was measured. This test has shown a good intra- and inter-rater reliability in healthy subjects [38].

Subjective perception of physical effort exerted during the intervention. The modified Borg scale is a standardized visual analog scale that assesses subjective perception of breathing difficulty (dyspnea) or physical effort exerted [39]. This consisted of a vertical scale labelled from 0 to 10, with corresponding verbal expressions of progressively increasing perceived sensations of intensity [40].

\subsection{Interventions}

After enrolment, the participants signed an informed consent form and immediately after this, baseline measurements were taken. At this point each participant was randomly assigned to the control group or one of the five experimental groups using a random number table.

\subsubsection{Control Group}

The control group did not receive any intervention; participants lay on a treatment table for the same amount of time as the intervention lasted in the experimental group 
(10 min). The data on hamstring muscle flexibility were collected at the start and at $30 \mathrm{~s}, 2,5$ and $10 \mathrm{~min}$. Ankle dorsiflexion was measured at the start and at the end of the intervention.

\subsubsection{Intervention Groups}

Five experimental groups were created, based on the SBL segment that was to receive SMR (plantar fascia, posterior part of the sural fascia, posterior part of the crural fascia, lumbar fascia and epicranial aponeurosis) (Figure 2). A physical therapist with more than 10 years of experience in manual therapy and soft tissue techniques gave a theoretical and practical explanation to the participants before the intervention. This person ensured during the intervention that the participants performed the intervention well. The intervention followed the recommendations of previous investigations and the applied pressure was the maximum tolerated by the patients (pushing into discomfort) with no pain [41]. Data collection on ankle flexibility and dorsiflexion (ROM) were measured the same way as the control group. Subjective perception of effort was analyzed at the end of the intervention in each group.

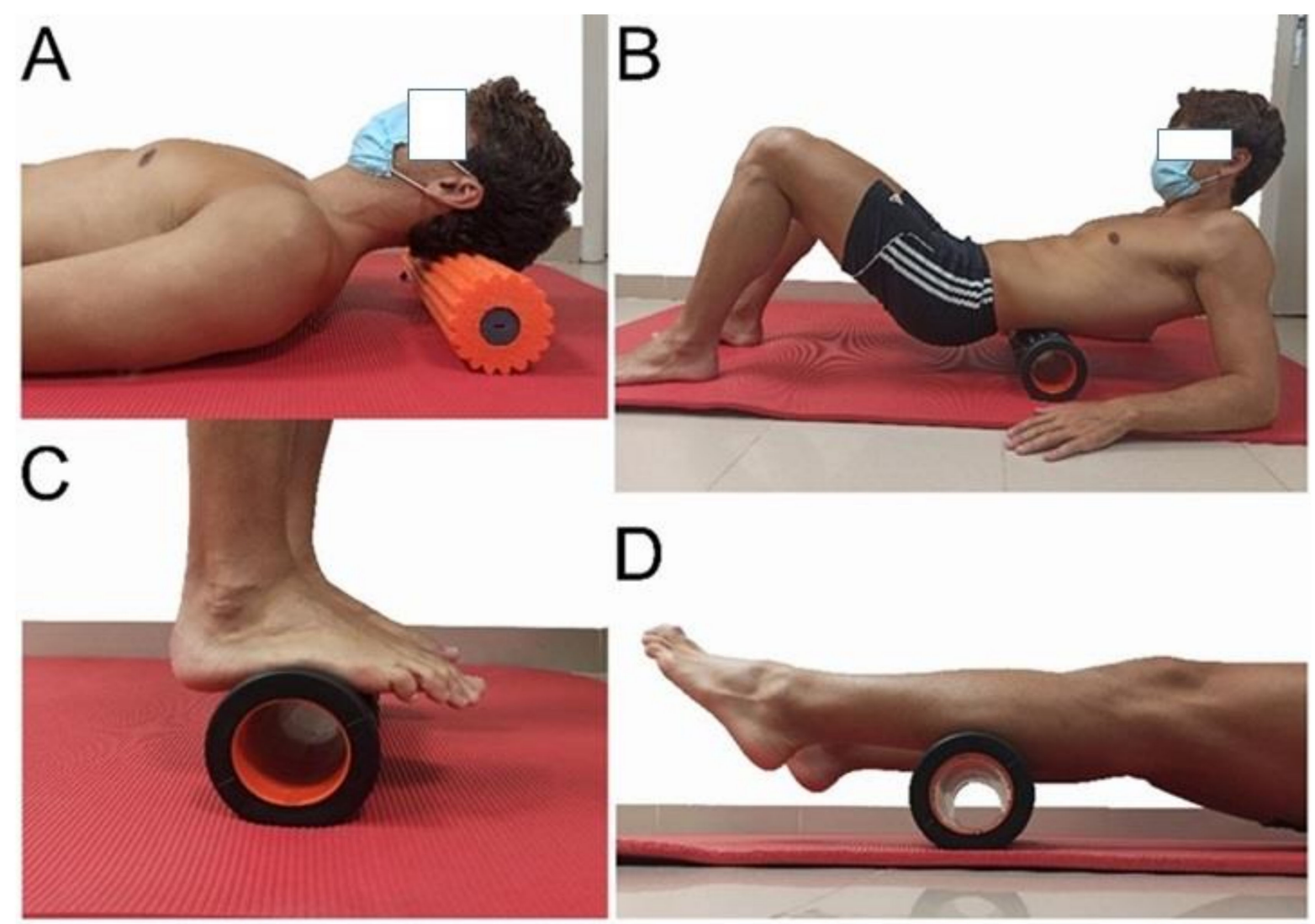

Figure 2. Interventions. (A) intervention to the epicranial aponeurosis, (B) thoracolumbar facia and erector muscles intervention, (C) plantar fascia and (D) posterior part of the sural fascia.

\subsubsection{Statistical Analysis}

Variables were described as mean and standard deviation for quantitative variables and frequency and percentage for qualitative variables. For the mean flexibility gain, a 95\% confidence interval was calculated. For k-group comparison of independent samples, ANOVA was performed for quantitative variables and Chi-square test for quantitative variables.

\section{Results}

The groups did not differ regarding age, gender or baseline measurements of ankle ROM or hamstring muscle flexibility $(p>0.05$, Table 1$)$. 
Table 1. Baseline characteristics of the participants grouped and compared by their intervention. Mean (standard deviation) for the quantitative variables; Frequency (percentage) for the qualitative variables; ANOVA test for the quantitative variables; Chi-square for the qualitative variables.

\begin{tabular}{|c|c|c|c|c|c|c|c|}
\hline \multicolumn{2}{|l|}{ Sample Size } & \multirow[t]{2}{*}{ Age } & \multicolumn{2}{|c|}{ Gender } & \multirow[t]{2}{*}{ Hamstring Flex. } & \multicolumn{2}{|c|}{ Dorsiflexion } \\
\hline & & & Women & Men & & Right & Left \\
\hline $\begin{array}{c}\text { Total } \\
\text { Intervention }\end{array}$ & 94 & $24.5(5.6)$ & $42(43.6 \%)$ & $52(56.4 \%)$ & $25.1(10.9)$ & $10.3(3.5)$ & $10.3(3.6)$ \\
\hline Control group & 15 & $26.1(6.4)$ & $46.70 \%$ & $53.30 \%$ & $28.0(12.0)$ & $10.5(2.5)$ & $10.6(3.2)$ \\
\hline Plantar fascia & 16 & $25.0(7.5)$ & $60.00 \%$ & $40.00 \%$ & $24.8(13.2)$ & $9.3(4.2)$ & $9.2(4.3)$ \\
\hline $\begin{array}{l}\text { Posterior part of the } \\
\text { sural fascia }\end{array}$ & 18 & $24.8(5.3)$ & $18.80 \%$ & $81.30 \%$ & $21.9(11.0)$ & $11.3(3.5)$ & $11.7(3.9)$ \\
\hline $\begin{array}{l}\text { Posterior part of the } \\
\text { crural fascia }\end{array}$ & 15 & $23.8(5.4)$ & $61.10 \%$ & $38.90 \%$ & $27.9(11.0)$ & $9.0(2.8)$ & $9.1(1.9)$ \\
\hline $\begin{array}{l}\text { Thoracolumbar fasciae } \\
\text { and erector muscles }\end{array}$ & 15 & $23.2(4.2)$ & $26.70 \%$ & $73.30 \%$ & $24.1(10.6)$ & $11.1(3.6)$ & $11.2(3.6)$ \\
\hline Epicranial aponeurosis & 15 & $23.5(6.4)$ & $46.70 \%$ & $53.30 \%$ & $23.4(7.4)$ & $11.0(3.7)$ & $10.5(4.4)$ \\
\hline$p$-value & & 0.521 & & & 0.545 & 0.232 & 0.245 \\
\hline
\end{tabular}

At the end of the intervention, it was observed that application of SMR to the superficial back line resulted in a statistically significant improvement in hamstring muscle flexibility (Table 2).

Table 2. Increase in hamstring flexibility $(\mathrm{cm})$ for each time interval and increase in dorsiflexion of ankle for each group (mean $(95 \% \mathrm{CI}))$.

\begin{tabular}{|c|c|c|c|c|c|c|c|}
\hline \multirow[b]{2}{*}{ Group } & \multicolumn{4}{|c|}{ Sit-and-Reach Test. Increase in Hamstring Flexibility } & \multicolumn{2}{|c|}{$\begin{array}{c}\text { Lunge Test. Increase in Ankle } \\
\text { Dorsiflexion }\end{array}$} & \multirow{2}{*}{$\begin{array}{c}\begin{array}{c}\text { Gain vs. } \\
\text { Perception } \\
\text { of Physical } \\
\text { Effort }\end{array} \\
\begin{array}{c}\text { Effort, } \\
\text { Mean (SD) }\end{array}\end{array}$} \\
\hline & $0-30 \mathrm{~s}$ & $0-2 \mathrm{~min}$ & $0-5 \min$ & 0-10 min & Right & Left & \\
\hline Control group & $0.56(-0.31 ; 1.45)$ & $1.23(0.29 ; 2.17)$ & $1.07(-0.21 ; 2.34)$ & $2.93(0.28 ; 5.58)$ & $0.13(-0.36 ; 0.63)$ & $0.14(-0.30 ; 0.57)$ & \\
\hline Intervention groups & $1.23(0.82 ; 1.65)$ & $2.78(2.24 ; 3.31)$ & $3.68(2.98 ; 4.38)$ & $5.22(4.39 ; 6.05)$ & $0.64(0.42 ; 0.86)$ & $0.66(0.45 ; 0.86)$ & \\
\hline Plantar fascia & $2.10(0.73 ; 3.46)$ & $3.83(2.26 ; 5.40)$ & $4.27(2.45 ; 6.08)$ & $5.47(3.38 ; 7.55)$ & $1.23(0.38 ; 2.08)$ & $1.03(0.41 ; 1.65)$ & $1.4(1.7)$ \\
\hline $\begin{array}{l}\text { Posterior part of the } \\
\text { sural fascia }\end{array}$ & $2.15(1.12 ; 3.18)$ & $3.71(2.59 ; 4.84)$ & $5.25(3.81 ; 6.69)$ & $6.56(4.51 ; 8.61)$ & $0.75(0.24 ; 1.26)$ & $0.78(0.11 ; 1.46)$ & $3.1(0.7)$ \\
\hline $\begin{array}{l}\text { Posterior part of the } \\
\text { crural fascia }\end{array}$ & $0.55(-0.003 ; 1.11)$ & $2.69(1.43 ; 3.95)$ & $4.31(2.72 ; 5.89)$ & $5.97(4.22 ; 7.72)$ & $0.86(0.43 ; 1.28)$ & $0.94(0.54 ; 1.35)$ & $2.1(0.7)$ \\
\hline $\begin{array}{c}\text { Thoracolumbar } \\
\text { fasciae and erector } \\
\text { muscles }\end{array}$ & $1.73(0.83 ; 2.63)$ & $3.23(1.83 ; 4.63)$ & $4.13(1.90 ; 6.36)$ & $6.07(4.22 ; 7.91)$ & $0.43(-0.13 ; 0.99)$ & $0.23(-0.12 ; 0.59)$ & $1.2(0.8)$ \\
\hline $\begin{array}{l}\text { Epicranial } \\
\text { aponeurosis }\end{array}$ & $0.37(-1.03 ; 1.76)$ & $1.93(0.25 ; 3.62)$ & $2.83(0.79 ; 4.86)$ & $4.07(1.62 ; 5.91)$ & $0.37(-0.12 ; 0.86)$ & $0.77(0.16 ; 1.37)$ & $0.8(1.0)$ \\
\hline
\end{tabular}

Bold: mean statistically significantly different from baseline.

The intervention groups had an improvement of $5.22 \mathrm{~cm}$, while the control group had an improvement of $2.93 \mathrm{~cm}$. Ankle ROM also improved on the DF-lunge test after the intervention (Table 2 and Figure 3).

When comparing the results from the different SBL segments, to determine the optimal location for SMR for hamstring flexibility, we found two different situations depending on the application time. For short interventions ( 2 min or less of SMR), the best results were obtained with SMR to the plantar fascia and the posterior part of the sural fascia (Table 2 and Figure 3). For longer interventions (5 or 10 min of SMR), more flexibility was gained with SMR to the posterior part of the sural fascia. Good results were also obtained with SMR to the thoracolumbar fascia and the posterior part of the crural fascia (Table 2 and Figure 4). 


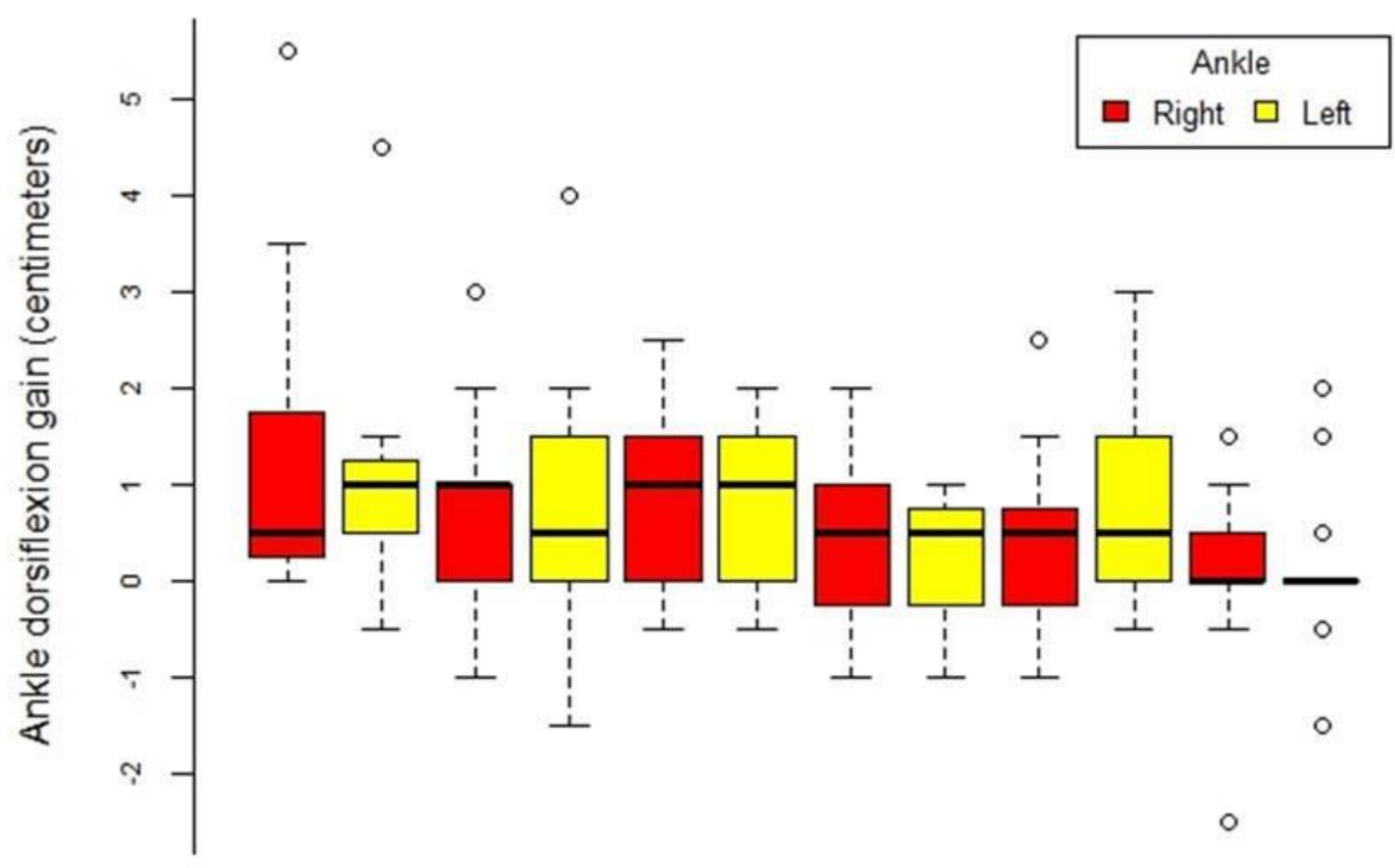

\section{Foot Calf Thigh Spine Head Control}

Figure 3. Box diagram of the gain of increase in ankle flexion-extension of the ankle by location of treatment location and by extremity (right and left).

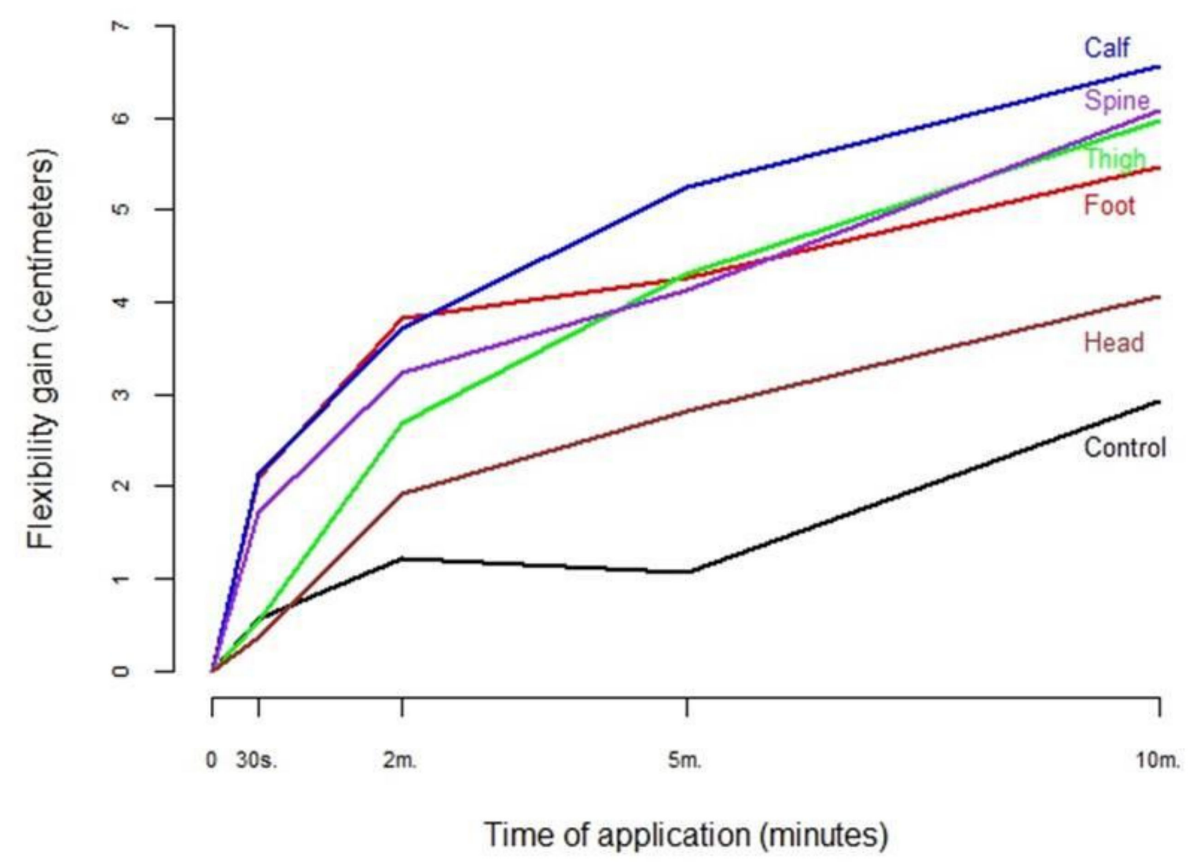

Figure 4. Hamstring flexibility gain $(\mathrm{cm})$ according to group.

Regarding intervention duration, overall, 70.5\% of hamstring flexibility gain was obtained with 5 min of SMR application, but after 30 s $23.5 \%$ of the total improvement could already be seen (Table 3 ). 
Table 3. Percentage of total flexibility increase achieved at each stop-time.

\begin{tabular}{ccccc}
\hline & $\mathbf{3 0} \mathbf{s}$ & $\mathbf{2} \mathbf{~ m i n}$ & $\mathbf{5} \mathbf{~ m i n}$ & $\mathbf{1 0} \mathbf{~ m i n}$ \\
\hline Intervention groups overall & 23.50 & 53.2 & 77.8 & 100 \\
Plantar fascia & 38.4 & 70 & 80 & 100 \\
Posterior part of the sural fascia & 32.7 & 56.6 & 72 & 100 \\
Posterior part of the crural fascia & 9.2 & 45 & 67.7 & 100 \\
Thoracolumbar fasciae and erector muscles. & 28.0 & 52.8 & 69.8 & 100 \\
Epicranial aponeurosis & 9.1 & 47.6 & 100 \\
\hline
\end{tabular}

When analyzing intervention duration according to the treated zone, we found that when SMR was performed on the sole of the foot, $70 \%$ of the gain was obtained at $2 \mathrm{~min}$, while all the other zones had around a 50\% gain after 2 min (Table 3 and Figure 4). No association was observed between perceived effort and flexibility gain (Table 2).

\section{Discussion}

The present study found that performing SMR on any segment of the SBL resulted in a statistically significant increase in hamstring flexibility and ankle dorsiflexion. These results reinforce the concept of the chain as an entity, not just from an anatomic perspective, as has been described previously [4,5], but also as a functional structure as reported in recent studies [42].

The segment found to affect hamstring flexibility most was the plantar fascia. The effects were greater especially when the foam roller was applied for relatively short times. This implication is not new and the results are similar to those observed by Grieve et al., when self-massage of the plantar fascia with a ball was performed for $5 \mathrm{~min}$ [43], or to the results described by Do et al. with self-massage for 5 min [44]. Joshi et al. obtained comparable results to ours when treatment was applied by a therapist over various sessions; they also found better results when the SMR was self-applied [42]. Even so, the results from this study are slightly lower than those described by Patel et al. [45].

Our results show that when the foam roller was applied for longer periods of time (from 5 to $10 \mathrm{~min}$ ), the segments of the thoracolumbar fasciae and erector muscles, and the posterior part of the sural fascia had more impact on hamstring flexibility. Previous studies observed an improvement in dorsiflexion but did not assess hamstring flexibility [46]. Other investigations also found increased ankle dorsiflexion following self-massage of the posterior part of the lower limb [47], but did not establish which fascial segment had the greatest effect.

The effects of SMR to each of these segments on hamstring flexibility may be due to the continuity, overlapping and compartmentalization of the muscular tissue by the fascia.

A possible explanation for the better results when SMR was performed on the plantar fascia is the significant fascial continuity, via the Achilles tendon, between the plantar fascia and the posterior part of the sural fascia [10]. In the same way, SMR application to the thoracolumbar fascia and erector muscles can be explained by the anatomical connection between the thoracolumbar fascia and the hamstring muscles via the sacrotuberous ligament $[9,48]$. Other studies have found significant improvements by combining the foam roll with passive movements [49]. However, it appears that the use of other therapies such as focal vibration may generate superior improvements [50]. Despite these results, the selling price of focal vibration is much higher than that of foam roll. For this reason, it could be interesting to use therapies such as focal vibration within a therapeutic treatment with the physical therapist and the use of the foam roll as a self-treatment for the patient.

Regarding the results obtained, there is a fascial structural relationship in the entire posterior chain; however, there is also a neurophysiological explanation. This possible explanation for the results obtained could be the one proposed by Bialosky JE et al. [51]. This author states that different manual techniques can generate viscoelastic and hypoalgesic effects through a model based on the fact that a mechanical stimulus initiates a chain of 
spinal, peripheral, and/or supraspinal neurophysiological events that would produce these changes at a distance even in distant areas such as the suboccipital region [52].

In summary, the present study demonstrates that the SBL can be considered a functional structure, since SMR application to any of its component segments improved hamstring flexibility and ankle dorsiflexion, the segments with the greatest effects being the plantar fascia (for short treatment duration) and the thoracolumbar fascia and erector muscles (for longer treatment duration). The results suggest that this technique could be effective both in rehabilitation and sports to enhance hamstring flexibility remotely.

The main limitation of this study is that short- and medium-term follow-ups have not been carried out, so we do not know how long the effects of the techniques used are maintained. Another limitation of this study is that more precise measurement tools such as myotonometry or tensiomyography could have been used. For future studies, the combination of functional measurements with these tools and short- and medium-term follow-up is recommended.

\section{Conclusions}

The present study demonstrates that the SBL can be considered a functional structure, as the application of SMR on any of its component segments improved hamstring flexibility and ankle dorsiflexion. The use of this treatment could be effective in both rehabilitation and sport to improve hamstring flexibility at a distance.

Author Contributions: Conceptualization, A.P.-B.; C.L-d.-C and P.F.; methodology, A.P.-B., J.R.-S. and L.L.-A.; formal analysis, J.C.M. and C.L.-d.-C.; investigation, N.L.-L., M.S. and P.F.; data curation, P.F. and M.C.-V.; writing-original draft preparation, A.P.-B., J.R.-S., C.L.-d.-C. and P.F.; writingreview and editing, all authors; supervision, A.P.-B. and C.L.-d.-C. All authors have read and agreed to the published version of the manuscript.

Funding: This research received no external funding.

Institutional Review Board Statement: The study was conducted according to the guidelines of the Declaration of Helsinki, and approved by the Ethics Committee from Universitat Internacional de Catalunya (CBAS1805, April 2018).

Informed Consent Statement: Informed consent was obtained from all subjects involved in the study.

Data Availability Statement: The data presented in this study are available on request from the corresponding author.

Acknowledgments: Thank you so much to all the volunteers.

Conflicts of Interest: The authors declare no conflict of interest.

\section{References}

1. Testut, L. Tratado de Anatomía Humana; Editorial Salvat: Barcelona, Spain, 1964.

2. Rouviere, H.; Delmas, A. Anatomía Humana Descriptiva, Topográfica y Funcional; Tomo 3. Miembros: Barcelona, Masson, 2006.

3. Gray, S. Gray's Anatomy; Random House Digital, Inc.: Manhattan, NY, USA, 2011.

4. Wilke, J.; Krause, F.; Vogt, L.; Banzer, W. What Is Evidence-Based About Myofascial Chains: A Systematic Review. Arch. Phys. Med. Rehabil. 2016, 97, 454-461. [CrossRef]

5. Krause, F.; Wilke, J.; Vogt, L.; Banzer, W. Intermuscular force transmission along myofascial chains: A systematic review. J. Anat. 2016, 228, 910-918. [CrossRef]

6. Myers, T.W. Anatomy Trains: Myofascial Meridians for Manual and Movement Therapists; Elsevier Health Sciences: Amsterdam, The Netherlands, 2009.

7. Van Wingerden, J.; Vleeming, A.; Snijders, C.; Stoeckart, R. A functional-anatomical approach to the spine-pelvis mechanism: Interaction between the biceps femoris muscle and the sacrotuberous ligament. Eur. Spine J. 1993, 2, 140-144. [CrossRef]

8. Vleeming, A.; Pool-Goudzwaard, A.L.; Stoeckart, R.; van Wingerden, J.; Snijders, C.J. The Posterior Layer of the Thoracolumbar Fascia I Its Function in Load Transfer from Spine to Legs. Spine 1995, 20, 753-758. [CrossRef]

9. Sato, K.; Nimura, A.; Yamaguchi, K.; Akita, K. Anatomical study of the proximal origin of hamstring muscles. J. Orthop. Sci. 2012, 17, 614-618. [CrossRef] [PubMed]

10. Stecco, C.; Corradin, M.; Macchi, V.; Morra, A.; Porzionato, A.; Biz, C.; De Caro, R. Plantar fascia anatomy and its relationship with Achilles tendon and paratenon. J. Anat. 2013, 223, 665-676. [CrossRef] 
11. Perez-Bellmunt, A.; Miguel-Perez, M.; Brugue, M.B.; Cabus, J.B.; Casals, M.; Martinoli, C.; Kuisma, R. An anatomical and histological study of the structures surrounding the proximal attachment of the hamstring muscles. Man. Ther. 2015, 20, 445-450. [CrossRef] [PubMed]

12. Dadebo, B.; White, J.; George, K.P. A survey of flexibility training protocols and hamstring strains in professional football clubs in England. Br. J. Sports Med. 2004, 38, 388-394. [CrossRef]

13. Woods, C.; Hawkins, R.D.; Maltby, S.; Hulse, M.; Thomas, A.; Hodson, A.; Football Association Medical Research Programme. The Football Association Medical Research Programme: An audit of injuries in professional football-Analysis of hamstring injuries. Br. J. Sports Med. 2004, 38, 36-41. [CrossRef] [PubMed]

14. Tondelli, E.; Boerio, C.; Andreu, M.; Antinori, S. Impact, incidence and prevalence of musculoskeletal injuries in senior amateur male rugby: Epidemiological study. Physician Sports Med. 2021, 1-7. [CrossRef] [PubMed]

15. Hennessey, L.; Watson, A.W. Flexibility and posture assessment in relation to hamstring injury. Br. J. Sports Med. 1993, 27, 243-246. [CrossRef]

16. Witvrouw, E.; Danneels, L.; Asselman, P.; D’Have, T.; Cambier, D. Muscle flexibility as a risk factor for developing muscle injuries in male professional soccer players. Am. J. Sports Med. 2003, 31, 41-46. [CrossRef]

17. Sherry, M.A.; Best, T.M. A comparison of 2 rehabilitation programs in the treatment of acute hamstring strains. J. Orthop. Sports Phys. Ther. 2004, 34, 116-125. [CrossRef] [PubMed]

18. Gabbe, B.J.; Bennell, K.L.; Finch, C.F. Why are older Australian football players at greater risk of hamstring injury? J. Sci. Med. Sport 2006, 9, 327-333. [CrossRef] [PubMed]

19. Engebretsen, A.H.; Myklebust, G.; Holme, I.; Engebretsen, L.; Bahr, R. Intrinsic risk factors for hamstring injuries among male soccer players: A prospective cohort study. Am. J. Sports Med. 2010, 38, 1147-1153. [CrossRef] [PubMed]

20. Hatzantoni, K.; Khan, W.S. Lower Limb Muscle Strains. In Orthopedics of the Upper and Lower Limb; Springer: Cham, Switzerland, 2020; pp. 385-390.

21. Rahr-Wagner, L.; Thillemann, T.M.; Mehnert, F.; Pedersen, A.B.; Lind, M. Is the use of oral contraceptives associated with operatively treated anterior cruciate ligament injury? A case-control study from the Danish Knee Ligament Reconstruction Registry. Am. J. Sports Med. 2014, 42, 2897-2905. [CrossRef] [PubMed]

22. Backman, L.J.; Danielson, P. Low range of ankle dorsiflexion predisposes for patellar tendinopathy in junior elite basketball players: A 1-year prospective study. Am. J. Sports Med. 2011, 39, 2626-2633. [CrossRef]

23. Watsford, M.L.; Murphy, A.J.; McLachlan, K.A.; Bryant, A.L.; Cameron, M.L.; Crossley, K.M.; Makdissi, M. A prospective study of the relationship between lower body stiffness and hamstring injury in professional Australian rules footballers. Am. J. Sports Med. 2019, 38, 2058-2064. [CrossRef]

24. Pruyn, E.C.; Watsford, M.L.; Murphy, A.J.; Pine, M.J.; Spurrs, R.W.; Cameron, M.L.; Johnston, R.J. Seasonal variation of leg stiffness in professional Australian rules footballers. J. Strength Cond. Res. 2013, 27, 1775-1779. [CrossRef]

25. Kovacs, M.S. The Argument against Static Stretching before Sport and Physical Activity. Athl. Ther. Today 2006, 11, 6-8. [CrossRef]

26. Blazevich, A.J. Adaptations in the passive mechanical properties of skeletal muscle to altered patterns of use. J. Appl. Physiol. 2019, 126, 1483-1491. [CrossRef] [PubMed]

27. Mohr, A.R.; Long, B.C.; Goad, C.L. Effect of foam rolling and static stretching on passive hip-flexion range of motion. J. Sport Rehabil. 2014, 23, 296-299. [CrossRef]

28. Cheatham, S.W.; Kolber, M.J.; Cain, M.; Lee, M. The Effects of Self-Myofascial Release using a Foam Roll Or Roller Massager on Joint Range of Motion, Muscle Recovery, and Performance: A Systematic Review. Int. J. Sports Phys. Ther. 2015, 10, 827-838. [PubMed]

29. Halperin, I.; Aboodarda, S.J.; Button, D.C.; Andersen, L.L.; Behm, D.G. Roller massager improves range of motion of plantar flexor muscles without subsequent decreases in force parameters. Int. J. Sports Phys. Ther. 2014, 9, 92-102. [PubMed]

30. Jay, K.; Sundstrup, E.; Sondergaard, S.D.; Behm, D.; Brandt, M.; Saervoll, C.A.; Jakobsen, M.D.; Andersen, L.L. Specific and cross over effects of massage for muscle soreness: Randomized controlled trial. Int. J. Sports Phys. Ther. 2014, 9, 82-91. [PubMed]

31. Schleip, R. Fascial plasticity-a new neurobiological explanation: Part 1. J. Bodyw. Mov. Ther. 2003, 7, 11-19. [CrossRef]

32. Castro-Piñero, J.; Chillon, P.; Ortega, F.; Montesinos, J.; Sjöström, M.; Ruiz, J. Criterion-related validity of sit-and-reach and modified sit-and-reach test for estimating hamstring flexibility in children and adolescents aged 6-17 years. Int. J. Sports Med. 2009, 30, 658-662. [CrossRef]

33. Ayala, F.; de Baranda, P.S.; Croix, M.D.S.; Santonja, F. Reproducibility and criterion-related validity of the sit and reach test and toe touch test for estimating hamstring flexibility in recreationally active young adults. Phys. Ther. Sport 2012, 13, 219-226. [CrossRef]

34. Mayorga Vega, D.; Viciana, J.; Cocca, A.; Merino Marban, R. Criterion-related validity of toe-touch test for estimating hamstring extensibility: A meta-analysis. Appear. Collect. 2014, 9, 188-200. [CrossRef]

35. Ayala, F.; de Baranda, P.S. Fiabilidad absoluta de las pruebas sit and reach modificado y back saber sit and reach para estimar la flexibilidad isquiosural en jugadores de fútbol sala. Apunts. Med. L'esport 2011, 46, 81-88. [CrossRef]

36. Hoeger, W.W.; Hopkins, D.R.; Button, S.; Palmer, T.A. Comparing the sit and reach with the modified sit and reach in measuring flexibility in adolescents. Pediatr. Exerc. Sci. 1990, 2, 156-162. [CrossRef]

37. Clanton, T.O.; Matheny, L.M.; Jarvis, H.C.; Jeronimus, A.B. Return to play in athletes following ankle injuries. Sports Health 2012, 4, 471-474. [CrossRef] 
38. Bennell, K.; Talbot, R.; Wajswelner, H.; Techovanich, W.; Kelly, D.; Hall, A. Intra-rater and inter-rater reliability of a weight-bearing lunge measure of ankle dorsiflexion. Aust. J. Physiother. 1998, 44, 175-180. [CrossRef]

39. Mahler, D.A.; Rosiello, R.A.; Harver, A.; Lentine, T.; McGovern, J.F.; Daubenspeck, J.A. Comparison of clinical dyspnea ratings and psychophysical measurements of respiratory sensation in obstructive airway disease. Am. Rev. Respir. Dis. 1987, 135, 1229-1233. [CrossRef]

40. Wilson, R.C.; Jones, P.W. A comparison of the visual analogue scale and modified Borg scale for the measurement of dyspnoea during exercise. Clin. Sci. 1989, 76, 277-282. [CrossRef] [PubMed]

41. Curran, P.F.; Fiore, R.D.; Crisco, J.J. A comparison of the pressure exerted on soft tissue by 2 myofascial rollers. J. Sport Rehabil. 2008, 17, 432-442. [CrossRef]

42. Joshi, D.G.; Balthillaya, G.; Prabhu, A. Effect of remote myofascial release on hamstring flexibility in asymptomatic individuals-A randomized clinical trial. J. Bodyw. Mov. Ther. 2018, 22, 832-837. [CrossRef]

43. Grieve, R.; Goodwin, F.; Alfaki, M.; Bourton, A.; Jeffries, C.; Scott, H. The immediate effect of bilateral self myofascial release on the plantar surface of the feet on hamstring and lumbar spine flexibility: A pilot randomised controlled trial. J. Bodyw. Mov. Ther. 2015, 19, 544-552. [CrossRef] [PubMed]

44. Do, K.; Kim, J.; Yim, J. Acute effect of self-myofascial release using a foam roller on the plantar fascia on hamstring and lumbar spine superficial back line flexibility. Phys. Ther. Rehabil. Sci. 2018, 7, 35-40. [CrossRef]

45. Patel, D.G.; Vyas, N.J.; Sheth, M.S. Immediate effect of application of bilateral self myo-fascial release on the plantar surface of the foot on hamstring and lumbar spine flexibility: A quasi experimental study. Foot 2016, 3, 7. [CrossRef]

46. Kelly, S.; Beardsley, C. Specific and Cross-Over Effects of Foam Rolling on Ankle Dorsiflexion Range of Motion. Int. J. Sports Phys. Ther. 2016, 11, 544-551. [PubMed]

47. Peacock, C.A.; Krein, D.D.; Silver, T.A.; Sanders, G.J.; von Carlowitz, K.A. An acute bout of self-myofascial release in the form of foam rolling improves performance testing. Int. J. Exerc. Sci. 2014, 7, 202. [PubMed]

48. Hoskins, W.; Pollard, H. The management of hamstring injury-Part 1: Issues in diagnosis. Man. Ther. 2005, 10, 96-107. [CrossRef] [PubMed]

49. Cheatham, S.W.; Stull, K.R. Comparison of a foam rolling session with active joint motion and without joint motion: A randomized controlled trial. J. Bodyw. Mov. Ther. 2018, 22, 707-712. [CrossRef]

50. Reiner, M.M.; Glashüttner, C.; Bernsteiner, D.; Tilp, M.; Guilhem, G.; Morales-Artacho, A.; Konrad, A. A comparison of foam rolling and vibration foam rolling on the quadriceps muscle function and mechanical properties. Eur. J. Appl. Physiol. 2021, 121, 1461-1471. [CrossRef]

51. Bialosky, J.E.; Bishop, M.D.; Price, D.D.; Robinson, M.E.; George, S.Z. The mechanisms of manual therapy in the treatment of musculoskeletal pain: A comprehensive model. Man. Ther. 2009, 14, 531-538. [CrossRef]

52. Rodríguez-Sanz, J.; Malo-Urriés, M.; Lucha-López, M.O.; Pérez-Bellmunt, A.; Carrasco-Uribarren, A.; Fanlo-Mazas, P.; Corral-deToro, J.; Hidalgo-García, C. Effects of the Manual Therapy Approach of Segments C0-1 and C2-3 in the Flexion-Rotation Test in Patients with Chronic Neck Pain: A Randomized Controlled Trial. Int. J. Environ. Res. Public Health 2021, 18, 753. [CrossRef] 